\title{
The Influence of Entrepreneurial Learning Design Meaningfulness on Student Entrepreneurial Competence
}

\author{
Walipah* \\ Economic Education Department \\ Universitas PGRI Kanjuruhan Malang \\ Malang, Indonesia \\ *walipah@unikama.ac.id
}

\begin{abstract}
Empirically, learning entrepreneurship in higher education, especially in Economic Education, Universitas PGRI Kanjuruhan Malang is oriented towards cognitive, affective and psycho-motor aspects. The formulation of the problem in this study is how the meaningfulness of entrepreneurial learning design affects the entrepreneurial competence of students in Economic Education and aims to explain the effect of the meaningfulness of entrepreneurial learning design on students' entrepreneurial competence. This type of research is explanatory research using a quantitative approach with data collection techniques through interviews and data analysis methods of distributing questionnaires. Simple Linear Regression results showed that there was a positive and significant influence between the meaningfulness of entrepreneurial learning designs on the entrepreneurial competence of students of Economic Education, Universitas PGRI Kanjuruhan Malang.
\end{abstract}

Keywords-significance of entrepreneurship learning design, student entrepreneurial competence

\section{INTRODUCTION}

The learning process of learning is carried out for caring participants who understand and understand well about something and will grow to become a person who thinks critically and becomes even better, both in terms of affective, cognitive and psychomotor. In order for the learning process to be more effective, an important effort to make to improve the quality of learning is learning or instructional science [1]. According to the Center for Entrepreneurial Leadership Clearinghouse on Entrepreneurship Education [2], entrepreneurship education is the process of providing concepts and skills for individuals to recognize opportunities that others ignore, and to have insight, self-esteem and knowledge to act where others hesitate. Entrepreneurship education as an activity aimed at the occurrence of an entrepreneurial process, namely starting from fostering a mindset and attitude and entrepreneurial skills so that it can generate business ideas / ideas, then starting a business and developing it through innovation.
In more detail, entrepreneurship includes elements of content, methods, and activities for the development of motivation, competence, and experience so that students can apply, manage, and participate in the process of adding value [3]. From the understanding of entrepreneurship education stated above, it can be summarized that entrepreneurship education is all contents, methods, and activities to develop thought patterns, attitudes, motivation, knowledge, skills, and entrepreneurial experiences, so that individuals are able to find business ideas / ideas to seize opportunities, starting a business, and developing a business that can provide added value to himself and / or others. In general, successful entrepreneurs are those who have competence and knowledge, skills and individual qualities including attitudes, motivations, and behaviors needed to carry out work or activities. This is reinforced by the statement of Suryana that an entrepreneur will not be successful if he does not have knowledge, skills and knowledge. Entrepreneurial competence is knowledge, attitudes and skills that are connected to one another, which are needed by entrepreneurs to be trained and developed in order to be able to produce the best performance in managing their business. Competencies that entrepreneurs must have are Managerial skills [4]. Entrepreneurs must be able to carry out the functions of planning, organizing, mobilizing and controlling so that the business they run can achieve the desired goals. These skills are an absolute prerequisite for becoming a successful entrepreneur.

\section{A. Managerial Skills}

Entrepreneurs must be able to carry out the functions of planning, organizing, mobilizing and controlling so that the business they run can achieve the desired goals. These skills are an absolute prerequisite for becoming a successful entrepreneur.

\section{B. Conceptual Skills}

The ability to formulate goals, policies and business strategies is the main foundation for successful 
entrepreneurship. Entrepreneurs must be extra hard to learn from various sources and learn from the experience itself and the experiences of others in entrepreneurship.

\section{Human Skills}

Sociable, sociable, sympathetic, and empathetic to others are skills assets that really support us to believe in business. With these skills, entrepreneurs will have many opportunities to start and develop their business.

\section{Decision Making Skills}

As an entrepreneur, the territory is faced with conditions of uncertainty. Various problems usually arise in situations like this. Entrepreneurs are required to be able to analyze situations and formulate various problems in order to find various management alternatives.

\section{E. Time Managerial Skills}

The inability to help with time makes the work pile up or never finish, so that it makes his soul upset and not calm. Time cooperation skills can facilitate the implementation of work and plans that have been outlined.

Results of preliminary observations of graduates in the Economics and Business Education Study Program, Faculty of Economics and Business, Universitas PGRI Kanjuruhan Malang. The last 2 years showed that unemployed graduates were approximately $30 \%$ of the total graduates as many as 76 Students. The large number of unemployed and the lack of interest in entrepreneurship is one of them caused by the low entrepreneurial competence possessed by students so that students are reluctant to do business or open a business after graduating from college. Higher education has three important roles in entrepreneurship education, namely as a facilitator of entrepreneurial culture, a skills mediator, and a regional business development locomotive [5]. In essence, the goal of higher education entrepreneurship education is not just to create job seekers, but also to create jobs [6].

Entrepreneurship Education in Economics Education Study Program, Faculty of Economics and Business, Universitas PGRI Kanjuruhan Malang is not much different from entrepreneurship learning in general, the results of preliminary observations show that 1). $75 \%$ of entrepreneurship learning is in the form of theory and the rest is practice, so that mastery of entrepreneurship subjects is slightly dominated by knowledge and attitudes while practice is weak; 2) The ability of students to create ideas and read business opportunities and student creativity is still low because students are shackled by job seekers instead of creating job opportunities (job creators); 3 ) The design of entrepreneurship learning so far has not been maximal in preparation so that it affects the implementation of lectures, output and outcomings, causing student competence in entrepreneurship to be low.

Seeing the learning of entrepreneurship courses like this, there must be efforts to improve entrepreneurship learning so that learning becomes meaningful for students, one of which is by compiling a meaningful entrepreneurial learning design, meaningful design, namely the existence of a whole, structure, framework or outline and a systematic sequence of activities [7]. Design can also be defined as a systematic planning process that is formalized before the development and implementation of an activity [3]. The hope is that if entrepreneurship learning is carried out using meaningful entrepreneurial learning designs, students will have high entrepreneurial competence to open their own businesses and can create job opportunities for others and give birth to independent young entrepreneurs in various fields of business.

\section{METHODS}

This research is a type of quantitative research with an explanatory research design. The variables in this study are the independent variables of meaningful entrepreneurial learning design and the dependent variable is entrepreneurial competence. The population in this study were students of economic education with a sample size of 37 students. The sampling technique was carried out by means of random sampling. The data collection technique used a questionnaire that had previously been tested for validity and reliability. The data analysis technique used simple linear regression with the help of the SPSS version 22.0 computer program.

\section{RESULTS AND DISCUSSION}

The results of the calculation of respondents' answers from the instruments distributed to students via google form can be explained that the entrepreneurial competence of students in Economics Education, Universitas PGRI Kanjuruhan Malang is quite good. In teaching entrepreneurship lecturers, they have designed and prepared entrepreneurial learning designs that are very meaningful for students, including through lectures, training, coaching, entrepreneurship competitions and business incubation. Lectures to create basic entrepreneurship (having a mindset and the ability to create jobs) training is carried out to foster intermediate competence (compile a feasible business proposal), while business coaching and business are to develop further competencies (running / developing a business).

The results of the simple linear regression test $\mathrm{R}$ Square are presented in Table 1 below:

TABLE I. RESULTS OF SIMPLE LINEAR REGRESSION ANALYSIS

\begin{tabular}{r|r|c|c|c|}
\hline Model & R & R Square & $\begin{array}{c}\text { Adjusted R } \\
\text { Square }\end{array}$ & $\begin{array}{c}\text { Std. Error of the } \\
\text { Estimate }\end{array}$ \\
\hline 1 & $777^{\mathrm{a}}$ & .604 & .592 & 1.27150 \\
\hline
\end{tabular}

From Table 1, it is known that the value of $\mathrm{R}$ Square is 0.604 , this value implies that the Effect of the Imperacy of Entrepreneurship learning design (X) on student entrepreneurial competence (Y) is $60.4 \%$, while 39.96 student entrepreneurial competence is influenced by other variables which are not examined. In an effort to increase the 
entrepreneurial competence of economic students. While the coefficients test can be seen in table 2 below.

TABLE II. RESULTS OF SIMPLE LINEAR REGRESSION ANALYSIS

\begin{tabular}{|c|c|c|c|c|c|c|}
\hline & \multirow[t]{2}{*}{ Model } & \multicolumn{2}{|c|}{$\begin{array}{c}\text { Unstandardized } \\
\text { Coefficients } \\
\end{array}$} & \multirow{2}{*}{\begin{tabular}{|c|}
$\begin{array}{c}\text { Standardized } \\
\text { Coefficients }\end{array}$ \\
Beta \\
\end{tabular}} & \multirow[t]{2}{*}{$\mathbf{t}$} & \multirow[t]{2}{*}{ Sig. } \\
\hline & & B & Std. Error & & & \\
\hline \multirow[t]{2}{*}{1} & (Constant) & 18.028 & 1.822 & & 9.897 & .000 \\
\hline & $\begin{array}{l}\text { Entrepreneurship } \\
\text { Learning Design }\end{array}$ & .439 & .060 & .777 & 7.303 & .000 \\
\hline
\end{tabular}

Source: Data processed, 2020

Dependent Variable: Entrepreneurial Competence

From Table 2 we can see that based on the significant value: from the Coefficients table, the significance value is $0.000<0.05$, so it can be denied that the variable meaningfulness of Entrepreneurship Learning Design (X) affects students' entrepreneurial competence.

Based on the value: it is known that the value of $t$ count is 7.303> t table 2.03011, so it can be denied that the variable meaningfulness of entrepreneurial learning design (X) affects the entrepreneurial competence of students (Y).

From the results of the analysis above shows that the meaningfulness of Entrepreneurship learning design is very important to improve the entrepreneurial competence of students of Economic Education, Universitas PGRI Kanjuruhan Malang. The results of this study are in line with those which state that entrepreneurship education needs to be clearly designed to achieve the goals of education in the form of student entrepreneurial competencies, namely basic competences, intermediate competencies and advanced competencies $[8,9]$. In an effort to improve entrepreneurial competence in Economics Education students, lectures are carried out comprehensively both in preparation, implementation, output and outcome. The preparation stage includes the syllabus, lecture contracts and assessment instruments. The lecture process is assessed through monitoring lecture implementation, lecture output through a business plane proposal prepared by students which is integrated and synergized with the Entrepreneurship Student Creativity Program while the outcomes are assessed through the efforts carried out and developed by students after taking entrepreneurship courses. With the existence of a meaningful entrepreneurship learning design, it provides real experiences for students so that it can improve entrepreneurial competence in the affective, cognitive and psychomotor domains of Economics Education students.

\section{CONCLUSION}

Based on the results of research and discussion, the following conclusions can be drawn:

- Entrepreneurship learning design needs to be clearly designed to achieve student competence in entrepreneurship which consists of basic, intermediate and advanced competencies.

- There is integration and synergy of content, activities, and methods to develop insights, mindsets, motivation, attitudes, skills knowledge and entrepreneurial experience so that students are able to find business ideas / ideas to seize opportunities.

\section{ACKNOWLEDGMENT}

We would like to extend our gratitude to the Chancellor, the Director of Postgraduate Program and the Head of Social Studies Education Study Program, Universitas PGRI Kanjuruhan Malang for contributing publication funds and the ANCOSH Committee for providing the opportunity and a forum to present research results in the form of proceedings.

\section{REFERENCES}

[1] N.S. Degeng, Ilmu Pembelajaran: Klasifikasi Variabel untuk Pengembangan Teori dan Penelitian. Bandung: Arasmedia, 2013.

[2] A.D. Handrimurtjahjo, "Model Pembelajaran Kewirausahaan Di Perguruan Tinggi," Jurnal Universitas Paramadina, vol. 10, no. 2, pp. 729-755, 2013

[3] P.L. Smith and T.L. Ragan, Instructional Design Upper sadleriver. New Jersey: Merill Prentice Hall, 2003.

[4] A. Rasmussen, K. Moberg and C. Revsbech, A Taxonomy of Entrepreneurship Education - Pepspectives on Goals, Teaching and Evaluation. Odense C, Denmark: The Danish Foundation for Entrepreneurship, 2015.

[5] L.J. Edward and E.J. Muir, "Promoting Entrepreurship at the UniversityGlamorgan Through Formal and Informal Learning," Journal of Small Business and Enterprise Developmen 12,4 : ABI / Inform Global, 2005

[6] L.M. Spencer and S.M. Spencer, Competence at Work, Models for Superior Performance. John Willey \& Sons Inc, 1993

[7] G.W. Gagnon and M. Collay, Disigning for Learning : Six Element in Contruktivist Classroom. California: Corwin press Inc, 2001

[8] R. Fitriati, Entrepreneureship Education : Toward Models In Savera Indonesia's University. Prosiding the 4 Th Internasional Conference on in Indonesia Studies “Unity, Diversity and Future”, 2011.

[9] Wardoyo, Pengaruh Pendidikan dan karakteristik Kewirausahaan terhadap Intensi berwirausaha mahasiswa pada Perguruan Tinggi Swasta di Jakarta, 2012 